\title{
Knowledge of The Health Volunteer Team About Basic Life Support (BLS) At Indonesia University of Education
}

\author{
Upik Rahmi*, Afianti Sulastri \\ Nursing Program Study, Faculty of Sport and Health, Universitas Pendidikan Indonesia \\ *upikrahmi@upi.edu
}

\begin{abstract}
Emergencies often occur in Indonesia due to natural disasters, technology, disputes or fights caused by humans. Accuracy in the way and time in providing basic life assistance is very important to note because it will membenatu continuity of human life. If the assistance provided is too late, there will be a risk of disability resulting in a decrease in the quality of human life itself. The provision of emergency and emergency services in Indonesia increased in 2011-2012 from $98.80 \%$ to $100 \%$ with increasing complaints from various victims.

The purpose of this research is to find out the knowledge of the Health Corps Volunteer Team of the Indonesian Education University about basic life support.

Research design with the quantitative descriptive approach, sampling with a total sampling of 60 respondents.

Results showed the respondents' knowledge into 2 categories: 46 participants $(76.67 \%)$, enough 14 participants $(23.33 \%)$ while there were no respondents.

Knowledge is influenced by several factors; some are based on gender, age and the faculty of study. Knowledge of important basic living rocks is given to students in addition to health. Suggestions for increasing knowledge and training on basic life support with the aim of numbers helps to reduce mortality.
\end{abstract}

Keywords: Basic Life Support, Knowledge, Volunteer 


\section{STRADA Jurnal Ilmiah Kesehatan}

DOI: $10.30994 /$ sjik.v9i2.286

ISSN: 2252-3847 (print); 2614-350X (online)

Vol.9 No.2 November 2020 Page.353-357

\section{BACKGROUND}

Basic life support (BLS) is an emergency procedure for patients consisting of several techniques such as cardio and pulmonary resuscitation (CPR), shock, and first aid treatment to maintain the life of the patient until the arrival of a medical facility or the person goes to the hospital. BLS including CPR is the first step of rapid recognition to provide emergency ventilation and circulation support in the case of breathing or cardiac arrest(Bakran and Šerić 2019). It has a combination of skills including mouth-to-mouth breathing and chest compression to normalize blood circulation to the brain and vital organs. Previous studies reporting on cardiac arrest, activation of the emergency medical service system (EMS), early cardiopulmonary resuscitation and defibrillation can make the difference between life and death (Bakran and Šerić 2019).

Basic life support (BLS) standards aim to improve the prognosis for cardiac arrest outside the hospital which is a critical factor (Sasson et al. 2010). The role of education is recognized as being able to increase knowledge and psychology by providing training to the community about BLS and clinical practice guidelines (Greif et al. 2015). Over the past few decades, the high level of interest in this field is evidenced by the increasing number of studies reporting on various BLS training approaches targeted at citizens, describing various content, formats, and training tools. However, this vast amount of information has not yet functioned to determine the optimal training strategy.

The ideal situation is to effectively train as many people as possible with the least time and resources. However, the same educational goals can be achieved or not with different methods and, more precisely, with different levels of investment of time and resources. However, there is no clear consensus about the minimum content and instruments to be included, the optimal length of training, or how the effectiveness of the intervention must be measured. The lack of consistent quality standards makes it difficult to recommend certain approaches to training citizens about BLS. Reviewing progress in the various training methods reported and weighing their success may be the first important step to determine the most effective formula. Therefore, the purpose of this systematic review is to describe the various BLS training methodologies reported for laypeople and to analyze their effectiveness in terms of acquiring practical skills and/or retention, identifying key educational aspects or ideal standards (Rodr1 et al. 2019). This study aimed to find out the knowledge of the health corps volunteer team about the Basic life support Assistance to members who had received Basic Life Assistance material

\section{METHODS}

\section{Participants and study}

A cross-sectional research design based on surveys (quantitative and observational) was carried out using a self-administered questionnaire in various universities/departments at the Indonesian University of Education, Indonesia. The participants are male and female students who are registered in various universities/majors of Universitas Pendidikan Indonesia. The participants were informed in advance about the purpose of the study. The participation of subjects is entirely voluntary and their identities are kept confidential.

\section{Data collection methods}

Kuesioner mandiri dan bilingual (bahasa Sunda dan bahasa indonesia) dikembangkan. Kuesioner mencakup 14 item berbeda yang diadaptasi dengan mengikuti manual BLS American Heart Association. Kuesioner diujicobakan pada 60 peserta dan dimodifikasi sesuai kebutuhan dan selanjutnya divalidasi oleh departemen layanan medis darurat 


\section{STRADA Jurnal Ilmiah Kesehatan}

DOI: $10.30994 /$ sjik.v9i2.286

ISSN: 2252-3847 (print); 2614-350X (online)

Vol.9 No.2 November 2020 Page.353-357

(EMS). Kuesioner survei dibagi dalam dua bagian. Bagian pertama melibatkan pertanyaan tentang rincian demografis peserta. Sementara itu, bagian kedua berkaitan dengan pertanyaan yang mencakup berbagai aspek BLS termasuk sejarah pelatihan CPR untuk mengevaluasi retensi pengetahuan yang sebenarnya oleh para peserta. Beberapa pertanyaan meliput kasus manajemen traumakarena kecelakaan dan cedera lalu lintas jalan merupakan salah satu penyebab utama kematian di Indonesia, terutama di Jawa Barat. Setiappertanyaan survei diikuti oleh empat opsi pilihan di mana satu jawaban itu benar / terbaik. Respons yang benar dari masing-masing item dikumpulkan untuk mendapatkan skor total.

\section{Statistical analysis}

Data collected were tabulated in MS Excel sheets and analyzed. The participants are students who have received BLS training including faculty of mathematical and natural sciences, faculty of sport and health, faculty of technical and teacher, faculty education, faculty Bisnis and economy, Faculty Bahasa and Sastra, faculty education elementary school and faculty education social science.

\section{RESULT}

A total of 60 participants completed the questionnaire, of the 17 (28.3\%) were males and $43(71.7 \%)$ were females. The result showed characteristic.

Table 1: Respondent Characteristic $(n=60)$.

\begin{tabular}{llcc}
\hline No & Characteristik & n & \% \\
\hline 1 & Gender & & \\
& Male & 17 & 28.3 \\
& Female & 43 & 66.7 \\
\hline 2 & Faculty & & \\
-. Faculty of mathematical and natural sciences & 15 & 25 \\
- Faculty of sport and health & 6 & 10 \\
- Faculty of technical and teacher & 10 & 16.7 \\
-. Faculty bisnis and economy & 6 & 10 \\
- Faculty Bahasa and Sastra & 6 & 10 \\
- Faculty education elementary school & 3 & 5 \\
- Faculty education social science & 14 & 23.3 \\
\hline \multicolumn{2}{r}{ Total } & 60 & 100 \\
\hline
\end{tabular}

The table shows that the gender of the respondents is female and most respondents are students from FPMIPA

Table 2: Knowledge of volunteer healthteam about basic life support at Indonesia University of Education

\begin{tabular}{lccc}
\hline & Knowledge & n & \% \\
\hline Good & 46 & $76,67 \%$ \\
Adequate & 14 & $23,33 \%$ \\
Less & 0 & $0,0 \%$ \\
\hline Total & $\mathbf{6 0}$ & $\mathbf{1 0 0 \%}$
\end{tabular}

Unit's voluntary corps team knowledge was mostly good (76.7\%), sufficient knowledge $(23.3 \%)$ and none had less knowledge 


\section{STRADA Jurnal Ilmiah Kesehatan}

DOI: $10.30994 /$ sjik.v9i2.286

ISSN: 2252-3847 (print); 2614-350X (online)

Vol.9 No.2 November 2020 Page.353-357

\section{DISCUSSION}

Motor vehicle accidents are a leading cause of death in adolescents and young adults throughout the world (Taylor, Abdullah, and Turki 2014).About three-quarters of road deaths occur in developing countries, and most men are involved in $80 \%$ (average value) of victims. In Saudi Arabia, motorized vehicles are the main means of transportation with 1 person killed and 4 others injured every hour (Taylor, Abdullah, and Turki 2014).

A report says road traffic accidents are a major health hazard in Saudi Arabia, especially during the month of Ramadan; especially the Jazan kingdom due to trauma from road accidents. Previous studies reported that trauma has increased significantly because of the increasing number of vehicles on the road (Shanks et al. 1994).

Therefore, a strategic prevention plan must be implemented earlier by all relevant sectors such as; health workers, police, transportation, and education aimed at reducing mortality. In all trauma cases, knowledge and skills of BLS (CPR) are needed and this prehospital care assistance can save human lives. Defending this fact, this study aims to assess the awareness and attitudes of Jazan University students about BLS (CPR). Awareness of BLS and CPR technique practices ensure the survival of patients long enough until medical assistance arrives and in most cases, itself is sufficient for the survival of the patient(Qassim 2014). Early identification and intervention of cardiac arrest victims by performing CPR is a basic knowledge of BLS, which helps in maintaining the lives of patients until medical treatment arrives and the patient is transferred to the Hospital for further management(Jordan and Bradley 2000).

Knowledge about BLS among medicine, pharmacy, dentistry, and nursing students is a health team that needs to be improved by applying better skills to save lives (Qassim 2014). Although there is no current evidence for improving patient outcomes from targeted BLS training for family members, this group is willing and able to learn skills about BLS (Cartledge et al. 2016). The results of the BLS (CPR) will help for education and public health service providers (Ahmad et al. 2018).

Students who receive BLS training will show a significant increase in BLS skills and retention with a time of 120 days after the training program (Priftanji et al. 2018). BLS training for clinical staff by creating a shared mental model will reduce the time when there are exercises with simulated cardiac arrest scenarios (Beck et al. 2019). This training has a significant direct effect on knowledge, self-efficacy, and chest compression skills; However, self-knowledge and skills decreased significantly after 3 months of training. Chest compression performance after 3 months of training will have a positive effect compared to the first post-test which is not significant.

Therefore, a retraining program to maintain knowledge and efficacy for a longer period needs to be carried out (Partiprajak and Thongpo 2016).Resuscitation " is the act of restoring the life or consciousness of someone who seems dead.(Srinivas, Kotekar, and Rao 2014).Most cardiac arrest victims do not receive adequate resuscitation in a critical time, thereby reducing survival time. So everyone in the community must know about BLS and CPR to save lives (Chandrasekaran et al. 2010).

\section{CONCLUSIONS}

Knowledge of the voluntary health corps team already has good knowledge about Basic Life Support but some still have enough knowledge. 


\section{STRADA Jurnal Ilmiah Kesehatan}

DOI: $10.30994 /$ sjik.v9i2.286

ISSN: 2252-3847 (print); 2614-350X (online)

Vol.9 No.2 November 2020 Page.353-357

\section{REFERENCES}

Ahmad, Awais, et al. 2018. "Knowledge of Basic Life Support among the Students of Jazan University, Saudi Arabia : Is It Adequate to Save a Life ?" Alexandria Journal of Medicine. https://doi.org/10.1016/j.ajme.2018.04.001.

Bakran, Katerina, and Monika Šerić. 2019. "Cardiopulmonary Resuscitation Performed by Trained Providers and Shorter Time to Emergency Medical Team Arrival Increased Patients ' Survival Rates in Istra County, Croatia : A Retrospective Study." : 325-32.

Beck, Stefanie, et al. 2019. "Models Improves Team Performance of the First Controlled Simulation Trial." 4(July): 2-8.

Cartledge, Susie, et al. 2016. "A Systematic Review of Basic Life Support Training Targeted to Family Members of High-Risk Cardiac Patients." Resuscitation: 1-8. http://dx.doi.org/10.1016/j.resuscitation.2016.04.028.

Chandrasekaran, Shanta, et al. 2010. "Awareness of Basic Life Support among Medical, Dental, Nursing Students and Doctors." 54(2): 121-26.

Greif, Robert et al. 2015. "European Resuscitation Council Guidelines for Resuscitation 2015 Section 10. Education and Implementation of Resuscitation.” 95: 288-301.

Jordan, Toni, and Paul Bradley. 2000. "Short Report A Survey of Basic Life Support Training in Various Undergraduate Health Care Professions." 47: 321-23.

Partiprajak, Suphamas, and Pichaya Thong. 2016. "Nurse Education in Practice Retention of Basic Life Support Knowledge, Self-Ef Fi Cacy and Chest Compression Performance in Thai Undergraduate Nursing Students." Nurse Education in Practice 16(1): 235-41. http://dx.doi.org/10.1016/j.nepr.2015.08.012.

Priftanji, Dorel, et al. 2018. "Performance and Retention of Basic Life Support Skills Improve with a Peer-Led Training Program." Currents in Pharmacy Teaching and Learning (XXXX): 0-1. http://dx.doi.org/10.1016/j.cptl.2018.03.006.

Qassim, Al. 2014. "Basic Life Support Knowledge of Healthcare Students and Professionals at Qassim University." 8(2).

Rodr1, Emilio, et al. 2019. "Training Adult Laypeople in Basic Life Support. A Systematic Review." (x).

Sasson, Comilla, Mary A M Rogers, Jason Dahl, and Arthur L Kellermann. 2010. "Predictors of Survival From Out-of-Hospital Cardiac Arrest A Systematic Review and Meta-Analysis." (October 2008).

Shanks, N J, M Ansari, M B FRCS, and King Khalid. 1994. "Road Traffic Accidents in Saudi Arabia." 34: 27-34.

Srinivas, H T, Nalini Kotekar, and Sindhu R Rao. 2014. "A Survey of Basic Life Support Awareness among Final Year Undergraduate Medical, Dental, and Nursing Students." 3(2): 91-94.

Taylor, Publisher, Yousef Abdullah, and Al Turki. 2014. "International Journal of Injury Control and Safety Promotion How Can Saudi Arabia Use the Decade of Action for Road Safety to Catalyse Road Traffic Injury Prevention Policy and Interventions ?" (November): 37-41. 